Religare, ISSN: 19826605, v.16, n.1, agosto de 2019, p.228-263.

\title{
O Ensino Religioso e a nova Base Nacional Comum Curricular (BNCC)
}

\author{
Religious Education and the new National Common Basic \\ Curriculum (BNCC)
}

Mauro Rocha Baptista ${ }^{1}$

\section{Resumo}

Com este artigo procuramos descrever os desenvolvimentos legislativos que levaram à proposta de atuação desenvolvida junto à Escola Estadual Adelaide Bias Fortes. Primeiramente abordando a intenção constitucional de um Ensino Religioso como disciplina obrigatória, mas de matrícula facultativa, para entender a sua presença em um Estado Laico, aprofundando essa relação para pensar os limites de uma prática confessional em oposição a uma ação mais influenciada pela(s) Ciência(s) da(s) Religião(ões). Metodologia fundamental para compreender os conhecimentos que fundamentam a nova Base Nacional Comum Curricular. Por fim, essa nova tendência é usada para repensar as práticas desenvolvidas na escola em 2017 e propostas para 2018.

Palavras-chave: Ensino Religioso; Base Nacional Comum Curricular; Estado Laico.

\begin{abstract}
This article describes the legislative developments, which lead to the action plan developed in the school "Escola Estadual Adelaide Bias Fortes". Firstly, we approached the constitutional intention of having a Religious Education as a compulsory subject, although its enrolment is voluntary, in order to understand its presence in a secular state, deepening this relation to think about the limits of

\footnotetext{
${ }^{1}$ Graduação em Filosofia pela Universidade Federal de São João del Rei (2000), mestrado (2005) e doutorado (2009) em Ciência da Religião / Filosofia da Religião pela Universidade Federal de Juiz de Fora. Atualmente é professor vinculado ao Departamento de Ciências Humanas da Universidade do Estado de Minas Gerais - Campus Barbacena onde é pesquisador do Núcleo de Pesquisa "Educação: Subjetividade e Sociedade". Tem experiência nas áreas de Filosofia da Religião, Filosofia Política, Ética e Educação, atuando principalmente na linha tênue entre Filosofia e Literatura com temáticas voltadas para a análise da religiosidade, da política e do messianismo e seus desdobramentos nas concepções de ética e experiência de autores como Franz Kafka, Walter Benjamin e Giorgio Agamben.
} 
Religare, ISSN: 19826605, v.16, n.1, agosto de 2019, p.228-263.

a confessional practice as oppose to an action influenced by the Studies of Religions. This methodology is fundamental do understand the new national common basic curriculum (BNCC). Finally, this new tendency is used to rethink the practices developed in the school during 2017, and the proposals for 2018.

Keywords: Religious Education; BNCC; secular state.

\section{Introdução}

As considerações traçadas neste artigo são frutos dos debates desenvolvidos ao longo da pesquisa "Uma política para a forma-de-vida: Inoperância, messianismo e profanação em Giorgio Agamben", executada através do Programa Primeiros Projetos com fomento da Fundação de Amparo à Pesquisa do Estado de Minas Gerais - FAPEMIG em convênio com o Conselho Nacional de Desenvolvimento Científico e Tecnológico - CNPq, a estas instituições todo agradecimento.

Ao longo do desenvolvimento desta pesquisa, junto ao Núcleo de Pesquisa "Educação: Subjetividade e Sociedade", procuramos ressaltar a importância da realização de uma forma-de-vida que integre a diversidade, respeitando as diferenças e rompendo com as estruturas sacralizadas. Agambenianamente, uma legítima forma-de-vida que não se limite às formas de vida impostas pela modernidade. Neste artigo não iremos explorar este aspecto teórico, mas enveredar para a parte do projeto que assumiu um viés prático na promoção do contato extensionista entre os discentes do curso de Ciências Sociais da Universidade do Estado de Minas Gerais - UEMG e os alunos do Ensino Fundamental da Escola Estadual Adelaide Bias Fortes, ambos em Barbacena, Minas Gerais. Este contato foi promovido através da disciplina de Ensino Religioso a partir de 2016 e está em atuação ainda, mantendo uma proposta de valorização da alteridade e da construção de uma identidade guiada pela tolerância e pelo respeito. 
Religare, ISSN: 19826605, v.16, n.1, agosto de 2019, p.228-263.

Visando uma melhor compreensão da proposta que vem sendo trabalhada pelo grupo no contexto da disciplina de Ensino Religioso apresentamos neste artigo uma análise de sua formação legal, valorizando as normas vigentes a partir da Constituição de 1988 e enfatizando nelas a relação entre a obrigatoriedade da disciplina em um contexto de Estado Laico. Posteriormente analisamos os desdobramentos curriculares para o Ensino Religioso entre o Currículo Básico Comum do estado de Minas Gerais e as três versões da Base Nacional Comum Curricular, nestas normas demarcamos a maior ênfase nos temas religiosos à medida em que se distancia da proposta do CBC e se aproxima da versão final da BNCC. Aos poucos a compreensão de que o Ensino Religioso não precisa deixar de falar de religião para existir em um Estado Laico é fundamental. Para enfim apresentar o que foi trabalhado pelo NPESS entre 2017 e 2018, já com a compreensão de que o Ensino Religioso deveria manter a discussão interreligiosa guiada pela metodologia da(s) ciência(s) da(s) religião(ões). Pelos limites desta exposição o texto final possui mais a função de apresentar as bases para o trabalho desenvolvido do que descrever ponto a ponto o que foi feito, para essa apresentação metodológica está sendo desenvolvido um novo artigo.

\section{Formação legal do Ensino Religioso}

Não pretendemos traçar um levantamento histórico da relação entre o estado brasileiro e a religião, para este estudo basta demarcarmos o tema a partir da Constituição de 1988, porque a intenção é discuti-lo a partir da realidade atual regida por esta norma. Neste sentido a tradição originada no descobrimento é menos relevante que o devido entendimento da realidade em que vivemos hoje. Por isso não trataremos da influência católica dos colonizadores, nem das práticas de burla dos povos indígenas e africanos, também não trataremos da formação de um império independente e cristão e de seus conflitos com as ideologias iluministas de grupos secretos, tão pouco das origens da república 
Religare, ISSN: 19826605, v.16, n.1, agosto de 2019, p.228-263.

com suas oligarquias tradicionalistas e o choque com as imigrações reformistas dos protestantes. Nos interessa pensar para onde tudo isso nos levou, no contexto da afirmação de uma república que se pretende laica, conforme fica expressa nos anos da redemocratização. Neste contexto é preciso pensar a condição de uma disciplina que, apesar de historicamente alcançar um patamar de ser normatizada no artigo 210, parágrafo 1ํㅜㄹ da Constituição da República Federativa do Brasil de 1988, até hoje enfrenta resistências a respeito de sua legitimidade em um estado efetivamente laico.

Neste sentido começaremos pelo artigo constitucional que prescreve a noção geral dos conteúdos do ensino fundamental e a especificidade do Ensino Religioso em meio à este.

Art. 210. Serão fixados conteúdos mínimos para o ensino fundamental, de maneira a assegurar formação básica comum e respeito aos valores culturais e artísticos, nacionais e regionais. $\S \mathbf{1}^{\mathrm{o}} \mathrm{O}$ ensino religioso, de matrícula facultativa, constituirá disciplina dos horários normais das escolas públicas de ensino fundamental (BRASIL, 2017a).

Conforme essa normatização o Ensino Religioso é apresentado como obrigatório, mas de matrícula facultativa. O fato de ser considerado como obrigatório é o reconhecimento de que a religião é parte constitutiva da identidade humana, não podendo ser relegada apenas aos ambientes sacros, uma vez que assim sendo, ela se tornaria fechada a uma única crença e favoreceria à intolerância. Ao contrário de romper com a laicidade do estado, essa inclusão do Ensino Religioso funcionaria como um respeito à religião como esfera integrante da subjetividade, mas, como as demais esferas, esta também não deve ser apartada da educação, para receber um tratamento que valorize a cidadania. Assim como a sexualidade que também representa uma esfera da subjetividade deve ser trabalhada na educação para que tenha um tratamento maduro e cidadão, também a religião deve ser trabalhada na educação, não como um 
Religare, ISSN: 19826605, v.16, n.1, agosto de 2019, p.228-263.

reforço dos aprendizados particulares, mas como um amadurecimento destes para uma vida tolerante.

Uma escola inteligente não pode deixar de fora o conteúdo religioso. Pôr para escanteio essa noção é esquisito, pois, se ela não é estranha à vida, como pode ser estranha à educação?

Se a Religião é presença constitutiva das existências humanas, e, desse modo, a educação religiosa é imprescindível, vê-se que o Ensino Religioso, como a ordenação intencional desse conteúdo no espaço escolar, torna-se tão sério quanto qualquer outro componente pedagógico, obrigando-nos a desenvolver a nossa competência para tal empreitada (CORTELLA, 2006, p. 19).

A obrigatoriedade do Ensino Religioso não fere a laicidade do estado se se compreende sua função de formação "educacional" e pública, e não simplesmente "religiosa" e subjetiva sobre esta esfera. Compreendendo que, assim como na História é possível observar um mesmo fato por ângulos diferentes, e que essa diferença de posição é fundamental para a constituição de uma visão mais global sobre os acontecimentos; assim como na Física é necessário compreender as aplicações das leis de Newton ainda que elas sejam refutadas por Einstein, uma vez que a refutação por uma nova teoria não reteria todas as utilidades práticas da anterior; assim como na Língua Portuguesa é preciso compreender que cada ambiente e cada gênero cobra uma forma de linguagem própria, portanto os usos da gramática não podem se limitar à norma culta a fim de evitar o preconceito linguístico; assim também é com o Ensino Religioso, que deve apresentar diferentes compreensões de um mesmo fato; teorias que se contrapõem, mas que não se excluem necessariamente; e regras de comportamento que precisam ser revisadas em prol da tolerância e do fim dos preconceitos.

Como qualquer outro conteúdo obrigatório, o Ensino Religioso deve ocupar seu espaço no ambiente escolar laico para promover uma integral formação do sujeito. Contudo, diferentemente dos outros conteúdos obrigatórios, o Ensino Religioso é apresentado como particularmente vinculado 
Religare, ISSN: 19826605, v.16, n.1, agosto de 2019, p.228-263.

à matrícula facultativa. Essa situação ímpar nos parece herança do modelo catequético de Ensino Religioso no qual se promovia "uma continuidade entre as comunidades religiosas e as escolas e reproduziu no interior destas as catequeses das Igrejas que conquistavam espaço" (PASSOS, 2006, p. 29). Este modelo de Ensino Religioso não permitia a laicidade do estado e feria a formação familiar dos alunos, uma vez que nele se reproduzia exclusivamente a posição de uma cultura dominante. A continuidade entre o espaço da educação social e a formação religiosa individual não permitia que se observasse as diferenças, encaminhando o Ensino Religioso para o exato oposto ao que é proposto teoricamente com sua obrigatoriedade. Ao invés de permitir o confronto de ideias e o amadurecimento das convicções, esse modelo catequético se cerca do pensamento igual e apenas reproduz sua própria compreensão.

Em tempos de redes sociais em que se bloqueia qualquer pensamento diverso e se conta a quantidade de "likes" gerados apenas entre aqueles que gostam do mesmo, quebrar com o modelo catequético de Ensino Religioso é fundamental, mas criar um espaço para que a formação religiosa seja discutida em meio à diversidade é ainda mais fundamental.

Certamente, as aulas de Ensino Religioso não podem mais estar pautadas por conteúdos que carreguem consigo a excludência das confessionalidades fechadas. Há necessidade de que se reveja o espaço escolar como um lugar de permanências transitórias no que se refere ao fenômeno religioso, capaz de conviver com as diferenças que personificam as escolhas das pessoas e respeitoso com suas histórias de relação com o Transcendente (MENEGHETTI, 2003, p. 95).

Ensinar o respeito às diferenças é uma das obrigações da escola, assim como o é criar um espaço em que as diferenças possam conviver. Essa convivência do diverso respeita e efetiva o Estado Laico, porque através dela se permite a inclusão dos sujeitos em uma sociedade realmente diversa. Uma sociedade na qual seu pensamento será confrontado com o de outros sem a 
Religare, ISSN: 19826605, v.16, n.1, agosto de 2019, p.228-263.

necessidade de se criar uma hierarquia entre os mais certos e os mais errados. A laicidade efetiva não acontece no espaço do velamento do diverso, ela precisa dos contrapontos para que não reflita apenas a exclusão que ilude sobre uma pretensa homogeneidade. A laicidade do estado precisa ser inclusiva, precisa garantir que todos tenham condições de argumentação sobre suas posições religiosas. Para ser laico o estado não pode velar a diversidade religiosa sob um fictício ateísmo metodológico, ele deve se conscientizar da diversidade de argumentos. A conscientização sobre a diversidade tem na escola seu locus privilegiado, por isso o Ensino Religioso obrigatório respeita a laicidade, mas a facultatividade de matrícula cria um constrangimento desnecessário. Ao normatizar a disciplina como facultativa, se está acreditando em uma postura confessional que já precisava estar distante da realidade do Ensino Religioso. Não é necessário normatizar a possibilidade do aluno se sentir incomodado nas aulas de Ensino Religioso por estas ferirem suas convicções, seria necessário evitar que essas aulas se mantivessem presas a padrões catequéticos e confessionais, algo que deveria ser atenuado quando o conteúdo fosse descrito na Lei de Diretrizes e Bases.

Quase uma década após a Constituição, o artigo 33 da Lei de Diretrizes e Bases de 1996 descreve o Ensino Religioso.

Art. 33. O ensino religioso, de matrícula facultativa, é parte integrante da formação básica do cidadão e constitui disciplina dos horários normais das escolas públicas de ensino fundamental, assegurado o respeito à diversidade cultural religiosa do Brasil, vedadas quaisquer formas de proselitismo. (Redação dada pela Lei no 9.475, de 22.7.1997)

$\S 1^{o}$ Os sistemas de ensino regulamentarão os procedimentos para a definição dos conteúdos do ensino religioso e estabelecerão as normas para a habilitação e admissão dos professores. (Incluído pela Lei no 9.475, de 22.7.1997)

$\S 2^{\mathrm{o}}$ Os sistemas de ensino ouvirão entidade civil, constituída pelas diferentes denominações religiosas, para a definição dos conteúdos do ensino religioso. (Incluído pela Lei $\mathrm{n}^{\mathbf{0}}$ 9.475, de 22.7.1997) (BRASIL, 2017b) 
Religare, ISSN: 19826605, v.16, n.1, agosto de 2019, p.228-263.

Um desenvolvimento que veda claramente qualquer forma de proselitismo, ao mesmo tempo em que resguarda a diversidade, mas não define conteúdos, deixando isso a cargo dos sistemas de ensino que devem para isso ouvir as entidades civis. A legislação, procura garantir um espaço para o Ensino Religioso no estado democrático e laico, mas ela mesma carece de uma maior clareza sobre qual seria esta função. Por isso mantém a noção de que, apesar de obrigatória a oferta, não é obrigatória a matrícula, apesar de impossibilitado de praticar o proselitismo deve ouvir as entidades civis na constituição de seus conteúdos, apesar de regular, a forma de admissão dos professores pode ser diversa das outras disciplinas se o sistema de ensino assim desejar. Por isso o Ensino Religioso não é tratado com paridade diante das outras disciplinas, uma vez que paira sobre a área uma crítica de que ela não presta aos ideais de um Estado Laico enquanto atende a particularidades das entidades civis. Se os professores podem ser indicados pelas entidades civis, seria o mesmo que dizer que as escolas poderiam ter como professor de História o ancião da cidade, ou um indicado pela associação de comércio como professor de Matemática. Como não se tolera esta interferência das entidades civis em outras disciplinas, resta o questionamento quanto aos motivos de se resguardar essa noção para o Ensino Religioso. O Estado Laico não condiz com essa interferência, mas assim ela foi legislada.

Vedar o proselitismo de uma designação religiosa também é incongruente com a noção de permitir às entidades civis participarem da decisão sobre os conteúdos da disciplina. Nenhuma outra disciplina sofre desta ingerência em seus conteúdos. Seria como pedir aos livreiros da cidade que ajudassem na confecção do currículo de literatura e produção de texto, se corre o risco capitalista de que as indicações destes estejam associadas à interesses comerciais seus. Da mesma forma as indicações das entidades civis, muitas vezes, são levadas também pela defesa dos próprios interesses. Como tratar do combate à 
Religare, ISSN: 19826605, v.16, n.1, agosto de 2019, p.228-263.

homofobia, conforme solicitado aos ambientes escolares nas atividades de maio, se as entidades civis indicarem que esse discurso é equivocado, já que as relações homoafetivas não devem ser religiosamente toleradas. Cria-se um conflito entre a prática da escola na atuação cidadã e as convicções de entidades civis que possuem suas intenções formais. Combater à homofobia, conforme o exemplo dado, não é uma prática de proselitismo, mas ainda assim pode ser vetada do currículo por uma postura que ultrapassa a catequese, mas se limita a uma posição ecumênica das entidades civis.

A prática ecumênica do Ensino Religioso é um segundo movimento de desenvolvimento da postura da disciplina, assumindo esse diálogo com as entidades civis, mas se limitando neste diálogo à participação de algumas entidades que se manifestam como mais próximas do mesmo embasamento que garantia a sustentação do modelo catequético. Em geral significa a abertura para o diálogo entre algumas designações do cristianismo. Essa postura não exclui o proselitismo, ela apenas vela a sua ação. Se mantém a noção de que o monoteísmo é superior a todas as outras formas de manifestação religiosa e que Cristo é o modelo máximo a ser seguido. Seria como ao invés de bloquear todos os que pensam diferente criar um grupo só com aqueles que pensam um pouco parecido. Uma "panelinha" que não é mais includente só porque encontra similaridades entre os parecidos. Ainda assim se promove a exclusão dos que não se parecem tanto assim. É possível tolerar que "este" não considere Maria como mãe de todos, mas não é possível entender porque "aquele" acredita em reencarnação, ou é possível aceitar que "estes" façam imagens de seus santos, mas não dá para compreender porque "aqueles" adoram suas entidades. Apesar de aumentar o grupo com o ecumenismo não se está produzindo de fato um combate ao proselitismo, e, sendo assim, a manutenção da facultatividade na matrícula faz sentido, embora não devesse. 
Religare, ISSN: 19826605, v.16, n.1, agosto de 2019, p.228-263.

Nestes termos, a recente Ação Direta de Inconstitucionalidade - ADI 4.439/DF, impetrada pelo Ministério Público Federal contra o artigo $11^{\mathrm{o}}$ do decreto no 7.107 de 11 de fevereiro de 2010, que firma acordo entre o Brasil e a Santa Sé, questiona a menção ao Ensino Religioso de forma confessional, presente neste decreto ${ }^{2}$ e faz indicações tanto contra o modelo catequético quanto contra o ecumênico. Ao apresentar o Ensino Religioso vinculado ao pensamento católico, ou ao de outras confissões, o decreto estaria rompendo com a intenção da formação para a diversidade, ainda que ele esteja prevendo o respeito a essa diversidade. Respeitar é um passo importante, mas para que o respeito seja amplo é necessário conhecimento sobre o outro. Esse conhecimento não pode ser adquirido se a Escola se fechar para uma reprodução das confissões pessoais de cada um. Neste sentido a ADI é direta ao afirmar que:

A escola pública não é lugar para ensino confessional e também para interconfessional ou ecumênico, pois este, ainda que não voltado à promoção de uma confissão específica, tem por propósito inculcar nos alunos princípios e valores religiosos partilhados pela maioria, com prejuízo das visões ateístas, agnósticas, ou com religiões com menor poder na esfera sóciopolítica (BRASIL, 2017f).

A denúncia de que o ecumenismo revalida apenas uma porção da esfera sócio-política e a cobrança para que as outras esferas de menor poder também sejam atendidas é extremamente relevante para que o Ensino Religioso se configure, não só como disciplina, mas também como área de conhecimento respeitosa da laicidade do estado. A inclusão da temática não-religiosa no discurso do Ensino Religioso só faz com que a área seja mais plena de sua função

\footnotetext{
2 "A República Federativa do Brasil, em observância ao direito de liberdade religiosa, da diversidade cultural e da pluralidade confessional do País, respeita a importância do ensino religioso em vista da formação integral da pessoa.

$\S 1^{\circ}$. O ensino religioso, católico e de outras confissões religiosas, de matrícula facultativa, constitui disciplina dos horários normais das escolas públicas de ensino fundamental, assegurado o respeito à diversidade cultural religiosa do Brasil, em conformidade com a Constituição e as outras leis vigentes, sem qualquer forma de discriminação (BRASIL, 2017e)".
} 
Religare, ISSN: 19826605, v.16, n.1, agosto de 2019, p.228-263.

social. A ADI não desmereceu a área, pelo contrário, ela permitiu que se ampliasse o seu reconhecimento, ainda que não tenha sido vitoriosa, suas contribuições ultrapassam o limite do julgamento.

Ainda que o argumento tenha sido derrotado nos debates do Supremo ${ }^{3}$ é importante salientar o exposto pelo relator, o ministro Luís Roberto Barroso, corroborando com sua posição de indicar apenas a forma não confessional como respeitosa da laicidade do estado ele apresenta os dados de uma audiência pública convocada por ele em 15 de junho de 2015 para a discussão deste tema e posterior desenvolvimento do relatório. Segundo sua descrição:

A grande maioria dos representantes de denominações religiosas, dos especialistas e das entidades da sociedade civil participantes defenderam a impossibilidade prática de conciliar os modelos confessional e interconfessional de ensino religioso confessional com a laicidade do Estado. Em síntese, dos 31 participantes da audiência, 23 defenderam a procedência da ação. Ainda, do total de participantes, 12 eram entidades de caráter religioso (incluindo posições não religiosas), representativas da diversidade religiosa do país. Destes, 8 defenderam a procedência da ação (BRASIL, 2017g, p. 18).

Com o apoio desta maioria o ministro propõe ainda que a modificação do artigo 33 da Lei de Diretrizes e Bases da Educação Nacional, "de modo a estabelecer que o ensino religioso em escolas públicas deve ostentar necessariamente natureza não confessional, com proibição de admissão de professores na qualidade de representantes de confissões religiosas" (BRASIL, $2017 \mathrm{~g}$, p. 18). Em sua proposta o ministro ao mesmo tempo chama as entidades civis para o diálogo quanto à forma com que o Ensino Religioso deveria assumir

\footnotetext{
${ }^{3} \mathrm{Na}$ conclusão de seu argumento, representação do que saiu vitorioso, o ministro Lewandowski não só defende o Ensino Religioso confessional como impõe limites para as escolas: "Não cabe a estes estabelecimentos de ensino negar à comunidade o direito de contar com instrução confessional de seu interesse, quando mais não seja por respeito à liberdade de aprender e de ensinar a religião num País que, conquanto laico, não deixa de ser plural e tolerante para com as todas as crenças e respectivas manifestações, de tal sorte a torná-las objeto de especial proteção no texto constitucional" (BRASIL, 2017h, p. 10).
} 
Religare, ISSN: 19826605, v.16, n.1, agosto de 2019, p.228-263.

para se realizar sem proselitismos quaisquer e reafirmando um Estado Laico, mas afasta estas entidades da escolha de professores e conteúdos, que devem seguir os padrões gerais para as demais disciplinas com concursos e não indicações. A proposta do fim da confessionalidade é aliada ao fim da interferência das entidades civis no desenvolvimento da disciplina. Apesar de perdedora essa proposta está muito mais presente nas intenções da nova Base Nacional Comum Curricular (BNCC) do que a proposta que se sagrou vencedora nos debates do Supremo.

\section{Desenvolvimento do Ensino Religioso: entre o CBC e a BNCC}

O argumento vencedor no Supremo em 2017 é o mesmo que estava presente na descrição do currículo do Ensino Religioso direcionado pelos estados a partir da LDB. Em nossa análise usaremos o Currículo Básico Comum, CBC, do Estado de Minas Gerais, por ser o estado onde atuamos. ${ }^{4}$ Este currículo foi constituído entre 2010 e 2014, com data de lançamento de dezembro de 2014, portanto, durante a vigência do decreto entre o Brasil e a Santa Sé (2010) e antes da audiência pública sobre a ADI contra ele (2015). De acordo com a proposta do CBC (MINAS GERAIS, 2017) devem ser trabalhados cinco eixos no Ensino

\footnotetext{
${ }^{4} \mathrm{O}$ primeiro contato com o Ensino Religioso, ainda como graduando de Filosofia, foi como docente na rede municipal de Barbacena-MG em 1998, cargo assumido como designado portando carta de indicação de uma entidade civil, no caso a Igreja Católica, onde atuava como catequista de Crisma e liderança arquidiocesana da Pastoral da Juventude. Na escola em que atuei era o único professor exclusivo para a matéria e dividia o cargo com professores de Matemática, História e Ciências que usavam a disciplina para completar suas cargas horárias. $\mathrm{O}$ segundo contato em 2003, já como especialista em Ciência da Religião, foi como ministrante do módulo de Fenomenologia da Religião em um curso preparatório para docentes, ação da SRE para formar seu quadro à época. Nesta ocasião também fui indicado por uma entidade civil, neste caso a Igreja Batista, com a qual mantinha apenas relações de discussão teórica. Nos dois casos o contato era marcado pela interferência direta das entidades civis, a formação do CBC parecia ser uma mudança de viés e veio associada à abertura do primeiro concurso público para a área no estado. Com o concurso se inicia o terceiro contato com a disciplina, desta vez como professor efetivo a partir de 2016, experiência a ser relatada na parte três do artigo.
} 
Religare, ISSN: 19826605, v.16, n.1, agosto de 2019, p.228-263.

Religioso5: 1) Autoconhecimento: o ser; 2) As relações na escola, na família e na sociedade; 3) ética e os valores; 4) A religiosidade; 5) Símbolos religiosos. Por vezes o CBC parece se envergonhar de tratar da disciplina como Ensino Religioso e procura fugir às discussões de religião propriamente ditas. Basta observar que dos cinco eixos, apenas dois trazem menção direta ao tema. ${ }^{6}$

No CBC cada eixo é dividido em habilidades que devem ser trabalhadas como introdução, ampliação ou conclusão em cada uma das séries dos anos finais do Ensino Fundamental. No primeiro eixo devem ser trabalhadas três habilidades, as duas primeiras versam sobre a identidade de si, desenvolvendo conteúdos como o cuidado consigo e com o próprio corpo e o respeito a individualidade de cada um (MINAS GERAIS, 2017, p. 10). A única habilidade deste eixo que trata diretamente da religião é a terceira "Conhecer a sua identidade religiosa, respeitando a religiosidade do outro. Identificar a diversidade religiosa presente em sua comunidade. Desenvolver atitudes de respeito e tolerância à diversidade religiosa, na convivência com o outro" (MINAS GERAIS, 2017, p. 11). De fato ela cumpre as intenções que observamos como sendo basilares para um Ensino Religioso em um Estado Laico, ao colocar o aluno em contato com a diversidade. Entre as orientações pedagógicas se destaca que,

Para estabelecer uma relação de reciprocidade na convivência com o outro, e para reconhecer que exteriorizar e interiorizar valores são atitudes que integram a formação do indivíduo, é necessário que o aluno conheça as bases das diferenças religiosas e compreenda que ter essa ou aquela religião é opção pessoal (MINAS GERAIS, 2017, p. 11).

\footnotetext{
${ }^{5}$ Apesar de o quinto eixo estar suprimido na introdução ele é desenvolvido posteriormente (MINAS GERAIS, 2017, p. 8).

${ }^{6}$ Neste caso com a supressão da introdução teríamos apenas um tema diretamente associado à religião.
} 
Religare, ISSN: 19826605, v.16, n.1, agosto de 2019, p.228-263.

Contudo, essa, que seria a base para todo o desenvolvimento do Ensino Religioso ficaria restrita aos dois últimos anos conforme a descrição do CBC. Compreender e respeitar as opções de cada um são elementos fundamentais para que o Ensino Religioso se organize em um Estado Laico. Essa proposta de tolerância que compreende que só se tolera o que se conhece, que exige a necessidade conteudística de se estudar "A história da Religiosidade do povo brasileiro" (MINAS GERAIS, 2017, p. 11) como forma de fundamentar o conhecimento que permite uma convivência salutar, não pode ser restringida aos anos finais. Ainda que seja necessário trabalhar o autoconhecimento, ele não pode, ao menos na disciplina de Ensino Religioso, ser tratado como algo díspar da formação religiosa. Esse contato com a diversidade como fruto de uma convivência cidadã deve ser a arkhé de todo o Ensino religioso, enquanto origem e manutenção de todo seu discurso.

Infelizmente a mesma retração pode ser observada no eixo 2 , que trata preferencialmente da relação entre escola e família e em que, com exceção da habilidade 2.7 que faz referência à diversidade religiosa, apresenta uma proposta que poderia ser trabalhada sem qualquer referência à religião. Por mais que seja necessário validar a disciplina em sua função de formação humanística e filosófica, não se pode perder de vista que ainda assim seu nome requer que esta discussão seja mediada pela temática da religião. A que se tomar o cuidado para que a disciplina de Ensino Religioso não assuma funções anteriormente exercidas pela Moral e Cívica, por mais que haja a necessidade de tratar de valores gerais, esses valores devem ser mediados por sua construção religiosa. Não significa dizer que o ateísmo, ou o agnosticismo seriam alijados da discussão, uma vez que seus valores são pensados ainda dentro deste mesmo ambiente, por vezes como oposição a alguns construtos históricos das religiões. Os próprios valores de constituição do núcleo familiar como uma estrutura basilar, podem e devem ser trabalhados diante das possibilidades das diversas religiões, que nem sempre 
Religare, ISSN: 19826605, v.16, n.1, agosto de 2019, p.228-263.

indicam o mesmo padrão. Valorizar que a família segue o padrão tradicional é deixar de reconhecer outras estruturas religiosas em que a poligamia, ou o regime comunitário de criação são priorizados. Diante da modificação do status da família tradicional, essa abordagem seria inclusive menos excludente do que assumir um conteúdo como o proposto na habilidade 2.2. “Família como espaço de vivência de valores como amizade, respeito, confiança, honestidade, responsabilidade" (MINAS GERAIS, 2017, p. 12). É possível que este conteúdo não diga muito respeito ao aluno que prefere ser criado na rua, porque quando entra em casa vê a mãe ser espancada pelo amante bêbado. Mas ele pode se identificar com um personagem como Percy Jackson ${ }^{7}$ que reproduz a mitologia grega e tem uma família disfuncional como a citada acima. A religião estaria presente juntamente com a tematização da família, mas não necessariamente pensando na confiança e respeito.

Já a habilidade 2.3 destaca ainda mais este elemento de civismo em completa disparidade com a temática da religião, ao indicar como orientação pedagógica que:

O aluno precisa compreender que a escola é um espaço de construção de conhecimento, mas também constrói valores e princípios que influenciam na sua formação e na sua realização como pessoa.

A partir do momento em que ele é reconhecido como membro desse grupo e se sente inserido nesse ambiente, ele reconhece os valores e princípios que a norteiam e deles se apropria (MINAS GERAIS, 2017, p. 12).

\footnotetext{
${ }^{7}$ Criado por Rick Riordan o personagem Percy Jackson é o pontapé inicial para a criação de toda uma mitologia própria. A primeira série de livros é Percy Jackson e os olimpianos, formada por: $O$ ladrão de raios (2005 - para função cronológica indicaremos o ano do original); O mar de monstros (2006); A maldição do titã (2007); A batalha do labirinto (2008); O último olimpiano (2009). Nesta série o herói descobre-se como um meio-sangue, filho de um deus (Poseidon) com uma humana, e precisa deter a recomposição de Cronos. O Deus do tempo que havia sido destronado por Zeus pretende retomar sua função e instaurar o caos. A premissa básica da organização desta mitologia é de que a cultura grega clássica permanece viva como fundamento da civilização ocidental.
} 
Religare, ISSN: 19826605, v.16, n.1, agosto de 2019, p.228-263.

O discurso, apesar de pretender trabalhar com a formação do aluno, acaba tratando a este como o objeto a ser moldado pela escola. Ignora assim o que o aluno traz de bagagem, inclusive ética e religiosa, ao indicar que a escola "constrói" aquilo que influencia o aluno "a partir do momento em que ele é reconhecido como membro" (MINAS GERAIS, 2017, p. 12). O aluno deve ser reconhecido pela escola, e esta irá lhe formatar, fazendo com que ele reconheça o que deve se apropriar. Não há a imagem de uma criação conjunta dos valores, nem da partilha de valores diversos, nem do reconhecimento da diversidade. Existe uma clara hierarquia entre quem ensina e quem aprende. Toda a indicação de uma diversidade fica para depois. Primeiro é necessário absorver os valores escolares, depois se aprende a ver o diverso. Uma inversão que impossibilita a verdadeira apropriação do que está sendo oferecido. Só posso me apropriar daquilo que escolho tomar posse, não da única possibilidade ofertada.

Ainda neste eixo, a única habilidade a tratar especificamente da religião não deve ser trabalhada no primeiro ano. "Valorizar a convivência com diferentes pessoas, respeitando a diversidade cultural e religiosa" (MINAS GERAIS, 2017, p. 12), só deve ser trabalhado depois da valorização do que a família oferece na composição da identidade do mesmo. Uma interpretação que apresenta os valores familiares e a assimilação às diretrizes da escola devessem ser tomadas como algo superior às indicações de uma diversidade religiosa, tema que poderia ser tomado como fundamento para a discussão dos eixos anteriores. A partir da noção de diversidade religiosa se poderia pensar a diversidade na formação das famílias; os valores adotados por cada grupo como associados a uma inclinação religiosa, ou a-religiosa; a organização da escola como influenciada por suas origens nas comunidades religiosas e o ensino como uma evolução das discussões dogmáticas destas. São valores que podem ser pensados a partir da mediação de uma compreensão de que a religião faz parte dessa estruturação da sociedade, não é preciso seguir o caminho inverso e pensar uma 
Religare, ISSN: 19826605, v.16, n.1, agosto de 2019, p.228-263.

sociedade aparte desta influência. Não é negar a influência da religião na constituição da sociedade moderna que a tornará mais laica, é compreender em que medida essa influência precisa ou não ser reavaliada.

Ainda que este seja o primeiro tema diretamente associado à religião, a ser tratado apenas a partir do sétimo, as orientações pedagógicas não são muito diversas do que se trata até então:

As comemorações e os eventos cívicos sociais que acontecem no espaço da Escola contribuem para o desenvolvimento dessa capacidade, ao possibilitar a convivência com diferentes pessoas e estimular as atitudes de respeito e tolerância a todas as formas de expressão da diversidade cultural e social (MINAS GERAIS, 2017, p. 14).

Mais uma vez o espaço escolar é transformado em catalizador da discussão de uma diversidade que o extrapola. Transmite um medo de pensar a diversidade para além daquilo que o aluno tem contato. Primeiro se deve manter fixo na família, então compreender os limites da escola, e com muito cuidado romper estes muros. Nem sempre uma escola vai dar a exata compreensão do que é a diversidade, este argumento mantém mais fácil a possibilidade de um discurso ecumênico, restrito a aceitar o diverso mais parecido comigo. A forma de construção do eixo, favorecendo a posição da família sobre a diversidade externa é temerária, assim como velar a discussão religiosa até esse tímido início no sétimo ano. A sequência da orientação traz uma primeira proposta efetivamente direcionada para o reconhecimento da diversidade. “O professor poderá, também, elaborar, junto com os alunos, questões para que eles entrevistem pessoas e conheçam os motivos que as levam a escolher ou pertencer a um determinado grupo religioso e sociocultural" (MINAS GERAIS, 2017, p. 14). As entrevistas podem ser o grande momento de tratar dessa diversidade, ir de encontro à comunidade, entender que existe o diferente vendo o diferente. $\mathrm{O}$ problema do CBC não é o que ele propõe, é esse envergonhamento em propor o 
Religare, ISSN: 19826605, v.16, n.1, agosto de 2019, p.228-263.

tema da religião de uma forma mais direta, o que fica ainda mais escancarado no eixo 3.

Se nos dois primeiros eixos a temática religiosa estava presente em uma das habilidades propostas, no terceiro ela é totalmente silenciada em nome de conteúdos como: "direitos e deveres do cidadão", "valores atitudes e comportamentos”, “ética e valores na vida” (MINAS GERAIS, 2017, p. 14-5). Como dito anteriormente o problema não é o que é proposto, mas porque uma disciplina destaca todo um eixo para não tratar nada de sua constituição básica. Se para manter a função do Ensino Religioso em um Estado Laico for necessário que ele não trate de religião que se substitua de uma vez a disciplina por outra. Se se pretende tratar dos valores em termos de Ensino Religioso então se deve levar em consideração as contribuições que a Ciência da Religião trazem para essa área.

Uma outra contribuição a ser elencada refere-se à recuperação da força espiritual das religiões. Num tempo marcado por tantos conflitos, também inter-religiosos, de afirmação de tantos dogmatismos e arrogâncias identitárias, há que desentranhar as forças de renovação espiritual em suas múltiplas formas de expressão. São forças espirituais que vêm conferindo à vida humana uma "fidelidade de fundo" e um "horizonte de sentido" essenciais, e que despontam para as pessoas a viabilidade de caminhos alternativos, marcados pelos valores da compaixão, cortesia e o cuidado com todas as formas de vida (TEIXEIRA, 2006, p. 77).

Os valores tratados na perspectiva da religião possuem uma "força espiritual" que não pode ser velada, pois é ela que garante um "horizonte de sentido" diferenciado. Resgatar este "horizonte de sentido" que mantém a tolerância ao diverso associada ao "cuidado com todas as formas de vida" é função primordial de um Ensino Religioso proposto para o Estado Laico. Contudo, isso não se faz tratando de "direitos e deveres" e de legislações, isso se faz na lida com a diversidade religiosa, no uso de exemplos de ação motivados 
Religare, ISSN: 19826605, v.16, n.1, agosto de 2019, p.228-263.

por convicções, como Gandhi ${ }^{8}$ ou Mãe Menininha do Gantois ${ }^{9}$, na interpretação de textos, como o Evangelho ou o Tao te Ching, na discussão de realidades religiosas que ultrapassam o limite da escola e da comunidade imediata. Esse tratamento não fere, mas realiza a proposta de um Ensino Religioso para o Estado Laico. Permitindo um Ensino que não deixa de ser Religioso e um estado que não deixa de ser laico.

Finalmente nos dois últimos eixos são tratadas questões de religião, infelizmente estas ficam restritas aos dois últimos anos, ou seja, no cômpito geral temos 5 eixos, apenas 2 tratando de religião diretamente (40\%); 18 habilidades, apenas 6 fazendo a referência direta (33\%); 4 anos, sendo que o primeiro é completamente privado dessa discussão direta, o segundo tem apenas uma habilidade a ser trabalhada e somente nos dois últimos se tratam de eixos realmente direcionados para a religião. O eixo 4 indica as habilidades de reconhecimento das diferentes religiões e da fundamentação do pluralismo religioso (MINAS GERAIS, 2017, p. 16-7), indicando a necessidade de um diálogo inter-religioso. As indicações deste eixo deveriam fazer dele o ponto central para toda a disciplina. Conteúdos como "crenças, doutrinas e rituais de diferentes práticas religiosas" e "as diversas formas de organização e de manifestação das religiões", exigem um trabalho de longo prazo que pode ser desenvolvido intercalando com outras discussões desde os primeiros anos. Basta observar que em história se trabalha com as sociedades arcaicas nos sextos anos, o que possibilitaria um trabalho interdisciplinar sobre as manifestações religiosas destes. Assim como é possível trabalhar o islã, o cristianismo original e a reforma

\footnotetext{
8 Mahatma Gandhi (1869-1948) foi um líder pacifista, adepto da satyagraha (uma forma de desobediência civil marcada pela não agressão), que se posicionou pela independência da Índia e sua manutenção como um estado único. De fato, a Índia se tornou independente da Inglaterra, mas se dividiu entre o Paquistão, majoritariamente mulçumano, e a Índia, de maioria hindu.

9 Maria Escolástica da Conceição Nazareth (1894-1986) foi a Iyálorixá responsável pela descriminalização do Candomblé e por manter um constante diálogo entre as tradições de matiz africana e o cristianismo, abrindo os terreiros para não iniciados e conquistando a possibilidade de assistir missas com as vestimentas típicas do candomblé.
} 
Religare, ISSN: 19826605, v.16, n.1, agosto de 2019, p.228-263.

protestante, com ênfases em suas propostas para além de seu impacto histórico imediato, o que exigiria que este eixo estivesse presente também no sétimo ano. O quinto eixo é o mais profundo, uma vez que se mescla à uma noção de linguagem simbólica mais avançada. Neste caso o amadurecimento dos alunos faz mais sentido, apesar de que o trabalho proposto com os textos sagrados deveria também estar incluído no eixo anterior.

Tomando um caminho diverso do apresentado pelo CBC a primeira proposta da BNCC (2017c) indicava três eixos fundamentais para a discussão do Ensino Religioso: 1) Ser humano - Eixo que envolve e amplia as relações filosóficas dos eixos 1, 2 e 3 do CBC, ao mesmo passo em que reduz algumas considerações mais associadas à Moral e Cívica que estavam presentes na proposta curricular de Minas Gerais; 2) Conhecimentos religiosos - Eixo que trabalharia com as propostas dos eixos 4 e 5 do CBC, mas com uma ênfase maior na característica religiosa do que a proposta no documento mineiro, resguardando o direito a uma religiosidade sem proselitismo; 3)Práticas religiosas e não religiosas - Eixo que insere a necessidade de se pensar a vida religiosa como dotada de lugares e práticas específicas, ao mesmo tempo em que exige também o respeito ao universo não religioso, mas igualmente dotado de um ethos próprio que também deve ser abordado. Neste eixo se revela toda a mudança de perspectiva entre o $\mathrm{CBC}$ e a BNCC, enquanto no primeiro procurava-se velar o sentido religioso da disciplina, neste novo documento o ateísmo, o cientificismo e o niilismo, são pensados em sua relação como resposta a uma proposta religiosa, ou seja, são práticas não-religiosas, práticas que tratam o mundo a partir de uma perspectiva que dispensa a religião, mas que, não abdicam de se relacionar com a religião. Esta interpretação do Ensino Religioso abre espaço para que ele seja pensado como uma parte fundamental do desenvolvimento da personalidade humana. 
Religare, ISSN: 19826605, v.16, n.1, agosto de 2019, p.228-263.

A segunda versão da BNCC (2017d) apresenta uma análise mais detalhada da função do Ensino Religioso e renomeia os eixos: 1) Identidade e diferenças Formato de título que demarca mais claramente a fase em que os alunos estão, um período de descobertas e distanciamentos, mas, sobretudo, um período em que é necessário trabalhar com o respeito a essa diversidade, para que a formação da identidade não signifique uma necessidade de violenta contraposição ao diverso; 2) Conhecimentos dos fenômenos religiosos/não religiosos - Nesta segunda versão a relação entre elementos religiosos e não religiosos é ainda mais ampliada de forma a se compreender que as "perspectivas seculares de vida" são modos de pensar a vida que se associam ao século, mas que não podem ser pensadas sem se relacionar a um movimento de transformação de pressupostos, ritos e mitos em estruturas secularizadas; 3) Ideias e práticas religiosas/não religiosas - Neste eixo com a inclusão das ideias juntamente com as práticas se abre caminho para uma maior discussão das "instituições religiosas e sua relação com a cultura, política, economia [...]", ou seja, é criado o espaço para a compreensão que o mundo secular não prescinde da religião, assim como a religião não se isola do mundo secular. Este é o elemento mais central para que a perspectiva acanhada do CBC seja substituída por uma postura mais convicta por parte da disciplina. O Ensino Religioso não pode se furtar de tratar de religião porque a religião é um tema inerente à constituição de nosso tempo, ainda que esse tempo se pretenda secular. A Educação carece de um Ensino Religioso consciente de sua função em tratar da religião porque ele é o único espaço em que a perspectiva secular não irá se sobrepor à religiosa, o espaço próprio para que as diferenças sejam respeitadas como diferenças, não como uma relação hierarquizada em busca de uma pseudo-homogeneidade.

Após um susto inicial quando o Ensino Religioso foi retirado da terceira versão da BNCC, ele reaparece na versão final (BRASIL, 2018), reafirmando a 
Religare, ISSN: 19826605, v.16, n.1, agosto de 2019, p.228-263.

trajetória das duas primeiras versões e se tornando ainda mais incisivo. São destacados como objetivos:

a) Proporcionar a aprendizagem dos conhecimentos religiosos, culturais e estéticos, a partir das manifestações religiosas percebidas na realidade dos educandos;

b) Propiciar conhecimentos sobre o direito à liberdade de consciência e de crença, no constante propósito de promoção dos direitos humanos;

c) Desenvolver competências e habilidades que contribuam para o diálogo entre perspectivas religiosas e seculares de vida, exercitando o respeito à liberdade de concepções e o pluralismo de ideias, de acordo com a Constituição Federal;

d) Contribuir para que os educandos construam seus sentidos pessoais de vida a partir de valores, princípios éticos e da cidadania (BRASIL, 2018, p. 434. Grifos nossos).

Nos próprios objetivos já se torna marcante a forma destacada com que a religião deverá ser tratada ao longo dessa nova BNCC. Não se pode prescindir dos conhecimentos religiosos para se pensar a realidade. Por isso é necessário compreender as manifestações religiosas que estão no entorno do educando, assim como a liberdade de crença não pode ser produzida diante da ignorância da crença do outro. Só é tolerante quem conhece e respeita o pensamento do outro, permitindo que ele seja outro, sem precisar da relação de submissão hierarquizada. O pluralismo de ideias não significa que uma precisa ser colocada como superior, ou mais correta, significa que existe uma pluralidade de perspectivas religiosas e seculares, e que todas devem se conhecer e se respeitar. O evolucionismo não é superior ao criacionismo, mas representam perspectivas teóricas, ambas com suas limitações e possibilidades. Refutar o criacionismo simplesmente por que o evolucionismo parece mais lógico e o mesmo que afirmar a existência de Deus porque é uma aposta mais interessante, como o faz Pascal $^{10}$. Ainda que eu ache mais lógico o evolucionismo, ou mais interessante a

\footnotetext{
${ }^{10} \mathrm{O}$ argumento de Blaise Pascal é apresentado em seu pensamento 233 (PASCAL, 1999, p. 91-5). Conforme ele, não acreditar em Deus não traria grandes ganhos se for verdade e traria grandes perdas caso fosse um erro. Ao passo que acreditar traria grandes ganhos caso fosse verdade e
} 
Religare, ISSN: 19826605, v.16, n.1, agosto de 2019, p.228-263.

existência de Deus, devo reconhecer que o outro lado tem seus argumentos para não acreditar em Deus, ou acreditar que a criação descende de um demiurgo.

Essa abertura para a diversidade sem que se delimite um ponto mais certo que outro nem sempre é possível em outras disciplinas, por isso é fundamental que o Ensino Religioso exerça esse papel. Por isso a própria BNCC destaca que:

Cabe ao Ensino Religioso tratar os conhecimentos religiosos a partir de pressupostos éticos e científicos, sem privilégio de nenhuma crença ou convicção. Isso implica abordar esses conhecimentos com base nas diversas culturas e tradições religiosas, sem desconsiderar a existência de filosofias seculares de vida (BRASIL, 2018, p. 434).

Essa abordagem do diverso pressupõe uma metodologia embasada na(s) Ciência(s) da(s) Religião(ões) e uma pesquisa centrada no diálogo para “combater a intolerância, a discriminação e a exclusão" (BRASIL, 2018, p. 434). Não existe combate à intolerância sem diálogo, e não existe diálogo sem conhecimento. A(s) Ciência(s) da(s) Religião(ões) é destacada neste momento como uma possibilidade de superar as propostas catequizadoras e ecumênicas de Ensino Religioso, se apresentando como uma abertura constante ao diálogo. Segundo Faustino Teixeira:

Dentre as diversas contribuições as Ciências da Religião para o "ensino do religioso", algumas merecem destaque. Em primeiro lugar, pode-se apontar a pista do "aperfeiçoamento do olhar e da escuta do mundo da alteridade". Há aqui uma importante contribuição advinda da Antropologia da Religião, no trabalho de campo, que privilegia de forma singular o "ver" e o "escutar" (TEIXEIRA, 2006, p. 73)

Atentar-se mais ao "ver" e ao "escutar" antes de se pronunciar sobre algo é fundamental para que o conceito emitido não se limite à uma mera reprodução de preconceitos que mantém o status quo da intolerância.

pequenas perdas em caso de erro. Justificando a escolha pela existência de Deus uma vez que "se ganhardes, ganhareis tudo; se perderdes, não perdereis nada" (PASCAL, 1999, p. 93). 
Religare, ISSN: 19826605, v.16, n.1, agosto de 2019, p.228-263.

Para esta proposta de Ensino Religioso não só os eixos são renomeados, como a abrangência inclui os anos iniciais do Ensino Fundamental. A partir de agora nomeados como unidades temáticas, a primeira unidade temática, Identidades e Alteridades, atende especialmente aos três primeiros anos, período não abrangido nem pelo $\mathrm{CBC}$, nem pelas versões anteriores da BNCC. Deve-se destacar que, se o CBC evitava tratar de temas diretamente voltados para a religião antes do sétimo ano, a nova BNCC indica como objeto a ser trabalhado já no primeiro ano a relação entre "Imanência e transcendência" (BRASIL, 2018, p. 440). Os "símbolos religiosos", tratados como eixo do oitavo e nonos anos no CBC, são objetos de conhecimento já no segundo ano (BRASIL, 2018, p. 442). Obviamente neste caso não se espera o tratamento madura da relação entre símbolos e linguagens propostos pelo $\mathrm{CBC}$, mas a habilidade de "Identificar, distinguir e respeitar símbolos religiosos de distintas manifestações, tradições e instituições religiosas" (BRASIL, 2018, p. 443). Estes objetos e habilidades estão associados à unidade temática Identidades e Alteridades, demonstrando uma preocupação muito mais aguda com a questão religiosa mesmo quando tratando das questões de autoconhecimento e identidade, conforme presente nas versões anteriores da legislação.

Desde o início se trabalha ainda com a unidade de Manifestações Religiosas, analisando questões como os "alimentos sagrados" no segundo ano (BRASIL, 2018, p. 442); "práticas celebrativas" e "indumentárias religiosas" (BRASIL, 2018, p. 444) no terceiro; até se aprofundar em uma análise de "ritos religiosos" e "representações religiosas na arte" (BRASIL, 2018, p. 446) no quarto. Essa formação básica sobre as manifestações religiosas permite que os trabalhos da terceira unidade temática, "Crenças religiosas e filosofias de vida", iniciado no quarto ano possa se desenvolver com toda força ao longo dos últimos anos da parte inicial do fundamental e por todos os anos do ciclo final. Uma formação 
Religare, ISSN: 19826605, v.16, n.1, agosto de 2019, p.228-263.

para o diálogo que se dá através da observação. O "ver" e "escutar" formando uma possibilidade consciente de diálogo.

A terceira unidade temática já inicia suas indicações tratando da(s) “ideia(s) de divindade(s)" (BRASIL, 2018, p. 446), indicando como habilidades "Identificar nomes, significados e representações de divindades nos contextos familiar e comunitário" e "Reconhecer e respeitar as ideias de divindades de diferentes manifestações e tradições religiosas" (BRASIL, 2018, p. 447). A posição ecumênica já é vetada aqui quando não se trata de uma divindade exclusiva. $\mathrm{O}$ monoteísmo é descartado como única possibilidade de visão religiosa já no quarto ano. A partir de então há um aprofundamento da formação teórica para o diálogo com ênfase nas narrativas orais no quinto ano (BRASIL, 2018, p. 448), tradição escrita no sexto (BRASIL, 2018, p. 450), atuação das lideranças no sétimo (BRASIL, 2018, p. 452), e um aprofundamento nas "crenças, convicções e atitudes" (BRASIL, 2018, p. 454) desenvolvendo habilidades como "analisar doutrinas das diferentes tradições religiosas e suas concepções de mundo, vida e morte" (BRASIL, 2018, p. 455) ou “Identificar sentidos do viver e do morrer em diferentes tradições religiosas, através de mitos fundantes" (BRASIL, 2018, p. 457), nos dois anos finais. É possível observar uma crescente temática entre as propostas de cada ano, mas em nenhum se menospreza a importância do tema da religião. A nova BNCC, ao contrário do que fica manifesto no parecer do Supremo, prioriza o debate da religião, mas não de forma confessional. Mostrando o maior respeito ao Estado Laico e aos avanços representados pelos estudos da(s) Ciência(s) da(s) Religião(ões), com uma formação totalmente voltada para o diálogo fundamentado e de qualidade. Retirando de suas propostas qualquer indicação de proselitismo. A seguir fazemos uma rápida apresentação de uma proposta trabalhada enquanto esta BNCC estava em discussão. 
Religare, ISSN: 19826605, v.16, n.1, agosto de 2019, p.228-263.

\section{Uma proposta para o Ensino Religioso a partir das discussões da nova BNCC}

Ao longo de 2017, em meu terceiro contato com o Ensino Religioso, procurei realizar algumas propostas que se não feriam o CBC, estavam mais próximas à BNCC que seria aprovada no fim do ano. Entre as ações desenvolvidas foram propostas oficinas sobre mitologia grega com os alunos do sexto ano, com a intenção de causar um estranhamento imediato entre a vivência diária de uma religiosidade culturalmente monoteísta e a prática amoral dos deuses gregos. Os personagens que guiavam essa abordagem foram fornecidos pelos alunos da disciplina em 2016, quando se iniciou esse novo contato com a área. Foi com essa indicação que travamos contato com Percy Jackson de Rick Riordan e Kratos do jogo God of War ${ }^{11}$. Tendo estes personagens como seu objeto de apoio em uma realidade que eles conheciam melhor do que o próprio professor os alunos mergulharam nessa perspectiva diversa observando que: como Atena ${ }^{12}$ as pessoas podem ser sábias e mesmo assim se deixar levar pelo sentimento de vingança, como na reação dessa deusa contra a traição de Medusa ${ }^{13}$; como Édipo ${ }^{14}$ podemos estar cegos para tudo que acontece ao nosso

\footnotetext{
${ }^{11}$ Kratos é o personagem principal da franquia de jogos God of War. Bastante reconhecido entre os adolescentes não se trata do deus grego Cratos, o poder, filho do rio Estige e Palas e acompanhante de Zeus (BRANDÃO, 2014, p. 236), mas de um personagem criado para destruir os deuses. Seus jogos trazem muitas referências aos mitos tradicionais da Grécia e um roteiro sobre sua saga original para matar Ares, o deus da guerra, foi publicado na forma de livro (VAREDEMAN; STOVER, 2012).

${ }^{12}$ De forma geral os deuses do politeísmo se manifestam como amorais, ou seja, estão além da definição de moralidade válida para os homens comuns. Um deus grego, por exemplo, não é completamente bom, nem completamente mau, por isso a deusa da sabedoria, Atena, pode ser também passional e se deixar levar por seus impulsos sentimentais (BRANDÃO, 2014, p. 90-2).

${ }^{13}$ Medusa era uma sacerdotisa de Atena que, assim como a deusa, deveria permanecer virgem. Porém ela foi seduzida por Poseidon, deus dos mares e rival de Atena na disputa pelo patronato da cidade de Atenas. Para se vingar Atena a transforma em um monstro que não pode ver ninguém que os transforma em pedra (BRANDÃO, 2014, p. 277-8).

${ }^{14}$ Édipo é um dos heróis mais reconhecidos na atualidade por conta da trilogia tebana escrita por Sófocles (Sófocles, 1990), especialmente pela primeira peça dessa tragédia em que é narrada sua desventura. Édipo estava destinado a matar o pai e se casar com a mãe, para evitar este fim seus pais procuraram se livrar do filho que foi abandonado. A força do destino levou Édipo a descobrir
} 
Religare, ISSN: 19826605, v.16, n.1, agosto de 2019, p.228-263.

redor, enxergando apenas o que nos interessa e achando que estamos mais certos que todos os demais; como Ícaro ${ }^{15}$ é possível se deixar levar por suas paixões e acabar perdendo tudo por um momento de prazer; ou que, assim como Ulisses ${ }^{16}$, qualquer um pode se vangloriar de uma vitória e se achar superior a tudo, mas sempre existe algo para nos superar; entretanto, acima de todos os demais exemplos trabalhados, os alunos puderam notar que não existe uma resposta uniforme que garanta segurança definitiva, o que só pôde ser obtido neste confronto com o diverso.

Se os alunos aprofundaram nessa diversidade grega, porque o professor se sentia seguro nela, sua reação ao desconhecido fez com que a proposta para o ano seguinte envolvesse outras mitologias que geravam interesses neles, como os deuses nórdicos presentes no universo da Marvel, ou as entidades africanas que interessavam para o trabalho na disciplina de História. Se o objetivo era gerar estranhamento entre os alunos era preciso que o professor também saísse de sua zona de conforto. Com a indicação da BNCC de trabalhar nos sextos anos com as tradições escritas, mas com a falta de profissionais habilitados na área para trabalhar as tradições orais do quinto ano, a proposta desenvolvida para 2018 visa trabalhar com estas religiosidades originárias, no sexto ano, destacando nela

seu futuro e a fugir de matar o pai que conhecia, cumprindo assim a profecia. Ele mata o pai, desvenda o enigma da esfinge e se torna rei em Tebas devendo desposar a rainha sua mãe. Tendo feito tudo isso sem saber de sua culpa, ele é advertido pelo adivinho cego Tirésias de que os rumos negativos da cidade eram responsabilidade sua. Ele ridiculariza o adivinho até descobrir a verdade. Como punição a si mesmo ele arranca seus olhos e admite que sua cegueira é maior que a do ancião (BRANDÃO, 2014, p. 182-9).

${ }^{15}$ Ícaro e seu pai Dédalo estão presos no palácio de Minos. Com seu gênio fora do comum, Dédalo cria uma asa capaz de permitir que os dois escapem. A asa é construída com penas e cera por isso é necessário que se mantenham igualmente distantes do mar, para que as asas não umedeçam e pesem mais que o suportável, e do sol, para que a cera não derreta. Dédalo consegue manter o equilíbrio necessário, mas Ícaro se fascina pelo sol e acaba cometendo o mais emblemático ato de hýbris, a loucura ou desmedida que acomete todos os heróis gregos (BRANDÃO, 2014, p. 345-6). ${ }_{16}$ Ulisses, como é mais conhecido em sua forma latina, ou Odisseu, em sua forma grega, é o personagem principal da Odisseia (HOMERO, 2014), a epopeia de Homero que narra sua tentativa de voltar para casa após a conclusão dos dez anos da guerra de Tróia. Após ser o responsável pela ideia do cavalo de Tróia, a estátua recheada de soldados que permite que os gregos vençam a guerra, ele se acha superior aos deuses e acaba desafiando Poseidon que o prende por mais dez anos no mar. A Odisseia narra o que acontece nestes anos (BRANDÃO, 2014, p. 614-25). 
Religare, ISSN: 19826605, v.16, n.1, agosto de 2019, p.228-263.

a transição entre o oral e o escrito. Proposta que está em execução sugerindo que os alunos criem o próprio personagem mítico fazendo uso dos conteúdos trabalhados. A criação de um personagem e de uma história próprias faz com que os alunos se sintam mais envolvidos com a proposta e sintam maior responsabilidade com o aprendizado sobre o outro. Assim como permitem mesclar tradições diferentes e a compreensão que aquilo que se manifestava tão diverso não está assim tão longe de sua própria realidade.

Já com os alunos do sétimo ano foi proposto em 2017 uma análise dos monoteísmos, assim eles puderam observar que o cristianismo tem raízes no judaísmo, e ambos são criticados pelo islamismo por não serem verdadeiramente monoteístas. Observaram que o antigo testamento não é apenas um caminho para Jesus, mas tem sua história própria, com personagens que também têm dúvidas como eles. Profetas que questionam suas obrigações para com Deus, reis que se interessam mais pelo comércio que pela construção da religião, patriarcas que sofrem com a dificuldade de serem ouvidos. Personagens humanos como os alunos também são, capazes de erros como os alunos também cometem, sujeitos a críticas e a revisões de seus posicionamentos. Com isso eles se sentem mais próximos da história dessa construção de uma identidade monoteísta, assim como se sentem desafiados pelas propostas do Messias Jesus.

Apesar de se identificarem majoritariamente com o cristianismo, raramente tiveram a oportunidade de colocar em questão os ensinamentos de Jesus e se perguntar até que ponto estou disposto a oferecer a outra face (Mateus 5:39-40 // BÍBLIA, 1985, p. 1847). Neste contexto um dos dramas mais difíceis para os adolescentes foi encarar a proposta de amar o inimigo (Mateus 5:44-45 // BÍBLIA, 1985, p. 1847), porque em tempos de redes sociais em que estamos cercado por aqueles que nos auto referenciam e bloqueamos todos os desafetos, o amor ao próximo não pode ser tratado isoladamente de suas consequências imediatas. Assim eles se depararam com algumas das 
Religare, ISSN: 19826605, v.16, n.1, agosto de 2019, p.228-263.

dificuldades geradas pela mensagem de amor da boa nova. Da mesma forma que tiveram que encarar a impossibilidade de considerar todo islâmico como terrorista, e mesmo de reconhecer que o terrorismo pode ser um ato de desesperada denúncia de uma crise social. Judeus passam a ser compreendidos em sua historicidade, e não apenas como os ignorantes que não reconhecem Jesus como salvador; o cristianismo é deparado com todas as suas exigências por uma conduta de vida que seja evangelizadora mais com o exemplo que apenas com palavras; o islamismo é entendido para além do terrorismo, com suas prescrições e sua abertura ao diálogo nas versões menos fundamentalistas. E mesmo o terrorismo é confrontado com as atitudes antiterroristas não menos danosas e com os terrores que vivemos a cada dia. Entretanto, acima de todos os ensinamentos históricos trabalhados, a compreensão de que somos parte de uma realidade plural, e que cada uma faz sentido ao mesmo tempo em que oferece dificuldades para ser assumida plenamente é o ganho maior deste debate. Reconhecer que a religiosidade do outro faz sentido, e que ele tem direito de ter uma religiosidade diferente da minha é reconhecer o direito do outro ser como ele é, e as dificuldades que eu mesmo tenho em ser como sou.

A partir das indicações da nova BNCC a proposta para 2018 manteve o aspecto de trabalhar com os alunos do sétimo ano os posicionamentos dos personagens históricos, mas distanciou-se da limitação a um trabalho com o monoteísmo, valorizando a qualidade de liderança destes personagens e transitando em uma gama maior de religiões, e mesmo de posturas a-religiosas. Para a análise das ações desses líderes foi antecipada uma análise dos paradigmas de heróis trabalhada em 2017 com os oitavos anos. Naquela oportunidade a ação com os oitavos anos foi direcionada para o auto reconhecimento das limitações de cada um em relação à prática do bem. Neste sentido foi utilizado os exemplos dos heróis dos filmes e das histórias em quadrinhos. Divididos em três paradigmas, conforme a proposta de Evans 
Religare, ISSN: 19826605, v.16, n.1, agosto de 2019, p.228-263.

(2009), estes heróis traziam para a realidade dos alunos envolvidos a dificuldade de enfrentar um posicionamento correto. O primeiro paradigma é o do SuperHomem $^{17}$, ao mesmo tempo capaz de fazer o que acredita ser certo e não sofrer críticas em sua ação (EVANS, 2009, p. 160-1). Com os alunos foi analisado como essa imagem pode tanto se refletir em um bem intencionado Jesus ${ }^{18}$, como em um líder fanático como Hitler ${ }^{19}$. Ambos podem acreditar no que estão fazendo e podem ser bem aceitos, mas as conclusões de seus atos são diametralmente opostas. Nem sempre ser aceito pela sociedade é uma vantagem, nem sempre o que se acredita ser certo, realmente é o melhor a ser feito. Ao trazer essa discussão para o sétimo ano em 2018, foi ampliada a noção de uma abdicação dos interesses pessoais para atender ao altruísmo que permite cumprir a habilidade da BNCC “identificar princípios éticos em diferentes tradições religiosas e filosofias de vida, discutindo como podem influenciar condutas pessoais e práticas sociais" (BRASIL, 2018, p. 453), ao analisar como as ações das lideranças são guiadas por suas convicções, religiosas ou não. E, ao mesmo tempo vendo como apenas

\footnotetext{
${ }_{17}$ O Super-homem é um personagem criado por Jerome "Jerry" Siegel e Joseph "Joe" Shuster entre 1933, data da sua primeira formatação, e 1938, data da publicação da sua primeira história oficial. Trata-se de um personagem vindo de um outro planeta (Krypton) que, estando na Terra recebe poderes especiais de nosso sol. Sempre luta para promover a justiça, abdicando de seus desejos pessoais para ser uma representação da ação altruísta perfeita, o que o torna um exemplo constantemente associado ao messianismo (KNOWLES, 2008, p. 140-4; ROBB, 2017, p. 37-48; MORRISON, 2012, p. 19-34). É o maior representante da Era de Ouro dos quadrinhos de heróis, quando estes personagens começaram a surgir e representavam, isoladamente, as grandes virtudes humanas (MORRISON, 2012, p. 17-78).

${ }_{18}$ Jesus Cristo é o mais reconhecido líder religioso do mundo. Tendo reunido em vida um pequeno grupo de judeus monoteístas ao seu redor sua mensagem embasada no amor a Deus e ao próximo como leis maiores das quais dependem todas as demais (Mateus 22: 34-40 // BÍBLIA, 1985, p. 1881) se tornou capaz de uma ampla reforma que gerou o cristianismo. Mesmo que posteriormente a religião cristã não tenha mantido estes ideais a intenção de Jesus era a de uma comunidade em que todos se respeitassem como iguais.

${ }^{19}$ Adolf Hitler (1837-1903) foi líder do partido Nacional Socialista que após se tornar Chanceler da Alemanha iniciou um governo amplamente aceito pela população deprimida com a derrota na Primeira Guerra. Seus ideias de supremacia da raça ariana eram sedutores, e as conquistas de avanços em um país recentemente devastado justificavam seus atos. Posteriormente, com a queda do reich, seu nome e sua ideologia nazista foram rechaçados, mas nos primórdios de seu governo ele chegou a ser cotado inclusive para o Nobel da Paz em 1939.
} 
Religare, ISSN: 19826605, v.16, n.1, agosto de 2019, p.228-263.

alguns destes são aceitos socialmente em suas práticas, em geral, quando representam a tradição da maioria.

No segundo paradigma se encontra a imagem de um Homem-Aranha ${ }^{20}$, constantemente levado a negar seus impulsos egoístas, vencendo sua vontade de não fazer o que lhe dá prazer em nome de sua responsabilidade, mas criticado pela mídia por fazer justiça com as próprias mãos (EVANS, 2009, p. 161-2). Assim como Gandhi ou Tiradentes ${ }^{21}$ sofreram perseguição por assumir uma postura que vai de encontro com o que é oficialmente estipulado. Confrontando os dois paradigmas os alunos percebem que nem sempre é fácil assumir a sua ideologia e a sua religiosidade, e que a sociedade nem sempre estará pronta para receber os posicionamentos assumidos, assim como é arriscado seguir cegamente a um líder, por mais carismático e bem intencionado que ele se pareça. $\mathrm{O}$ fato de Homem-Aranha ser mais jovem é um elemento destacado pelos alunos como condizendo com a falta de aceitação do mundo adulto das posições assumidas pelos mais jovens. Nesse sentido o exemplo de Malala ${ }^{22}$ e sua luta pela educação, mesmo sendo perseguida, se apresenta como algo que gera o interesse direto desses alunos.

\footnotetext{
${ }^{20}$ O Homem-Aranha é um personagem criado por Stanley Lieber (Stan Lee) e Steve Ditko em 1962, diferentemente do Super-Homem, o Homem-Aranha foi criado para retratar um adolescente comum, o roteirista Stan Lee optou por trocar o experiente desenhista Jack Kirby por Steve Ditko exatamente porque não queria que o herói tivesse os traços clássicos e musculosos dos outros heróis, ele devia ser um herói tipicamente nerd. Um herói que retratasse, inclusive as fragilidades humanas, como a tentativa de obter lucro com seus poderes. O Homem-Aranha só passa a atuar como herói depois de se sentir responsável pela morte de seu tio, mas, mesmo assim não é tratado como herói pela mídia que vê nele apenas um justiceiro que quer se colocar acima da lei (KNOWLES, 2008, p. 159-61; ROBB, 2017, p. 140-5; MORRISON, 2012, p. 118-24). O HomemAranha é um dos principais representantes da Era de Prata dos quadrinhos de heróis quando os heróis se tornaram mais comuns e suscetíveis aos vícios (MORRISON, 2012, p. 79-148).

${ }^{21}$ Joaquim José da Silva Xavier, o Tiradentes (1746-1792), foi um inconfidente que enfrentou a coroa portuguesa por seus ideais de uma maior liberdade comercial e intelectual. Sua imagem é redefinida para aproximá-lo à de um Jesus que se sacrifica por todos, se tornando um patrono das lutas pela independência do Brasil.

${ }^{22}$ Malala Yosafzai (1997) é a mais jovem ganhadora do prêmio Nobel da Paz, em 2014 com 17 anos. Paquistanesa e mulçumana ela sofreu um atentado por resistir à proibição de mulheres estudarem. Tendo sobrevivido segue em luta pelo direito irrestrito à educação.
} 
Religare, ISSN: 19826605, v.16, n.1, agosto de 2019, p.228-263.

Por fim, o terceiro paradigma apresenta os mutantes que, como Magneto ${ }^{23}$ optam por se organizar em torno ao seu grupo e lutar contra os que pensam diferente (EVANS, 2009, p. 162-7). Com esse paradigma refletem sobre os terroristas, os fundamentalistas e mesmo a crescente onda de nacionalismos. Entretanto, para além dos paradigmas, o importante é a compreensão gerada nos alunos de que nem sempre é fácil fazer o que parece ser mais certo, e nem sempre o que parece ser mais certo é o melhor a ser feito. Os questionamentos permitem uma revisão de suas condutas e mesmo de sua religiosidade. Neste último aspecto com os alunos de 2018 se reflete a postura diferenciada de Martin Luther $\mathrm{King}^{24}$, assumido como inspiração para a conduta mais disposta ao diálogo do líder dos X-Men professor Xavier, e a postura mais sanguínea manifesta por um Malcolm $\mathrm{X}^{25}$, igualmente usado para se pensar no personagem de Magneto. Lutar pelo seu grupo pode trazer posturas diferentes, sujeitas a críticas e vitórias. Com os sétimos anos em 2018 estamos aproveitando também para trabalhar a relação entre o respeito ao líder e o desejo de se juntar a ele, com a idolatria e o fanatismo que levam a agir sem pensar.

\footnotetext{
${ }^{23}$ Os Mutantes são uma criação de Stan Lee e Jack Kirby de 1963, refletem tanto o medo de uma guerra nuclear e suas possíveis mutações radioativas, quanto a perspectiva característica da Era de Prata de que os heróis devem refletir as limitações humanas. Este grupo de adolescentes que se descobrem diferentes dos demais devem lidar com a desconfiança e o preconceito dos nãomutantes. De um lado se reúnem aqueles que querem lutar por uma vida de igualdade, de outro aqueles que optam por demonstrar a sua diferença como um elemento que merece destaque, ainda que isso indique que será necessário um conflito. O professor Charles Xavier reúne os Xmen como um grupo que anseia pela convivência pacífica, enquanto Magneto, reúne a Irmandade Mutante como um grupo que pretende se sobrepor aos simples humanos não-mutantes. Ambos são temidos pela sociedade (KNOWLES, 2008, p. 195-7; ROBB, 2017, p. 151-3; MORRISON, 2012, p. 205-8).

${ }^{24}$ Martin Luther King Júnior (1929-1968) foi um importante líder do movimento dos direitos civis dos negros nos Estados Unidos, influenciado por Gandhi também promove uma ação não violenta e procura conscientizar através de seus sermões, como ministro batista, e discursos, como destacado representante político. O personagem do professor Xavier se enquadra com a sua atuação (HOWE, 2013, p. 57).

${ }^{25}$ Al Hajj Malik Al-Shabazz, o Malcolm X, é fundador da Organização para a Unidade AfroAmericana, de tendência separatista que acreditava que a violência era um importante meio para a defesa dos oprimidos, o que inspirou a ação dos Panteras Negras em seu combate a qualquer forma de discriminação contra os negros. O personagem de Magneto adotaria uma postura similar a esta (HOWE, 2013, p. 57).
} 
Religare, ISSN: 19826605, v.16, n.1, agosto de 2019, p.228-263.

Com a passagem desta temática para o sétimo uma nova proposta foi pensada para o oitavo ano de 2018. Neste caso tem sido trabalhado com os alunos as convicções individuais e em que medida suas escolhas são levadas por influências outras. Assim se contempla a habilidade de "Discutir como filosofias de vida, tradições e instituições religiosas podem influenciar diferentes campos da esfera pública (política, saúde, educação, economia)” (BRASIL, 2018, p. 455). Para pensar essas influências a estratégia traçada foi a de pedir que os alunos desenvolvessem uma história que parasse em um momento em que uma decisão devesse ser tomada. Cada grupo de alunos desenvolveu suas histórias e a mais votada por eles foi a usada para a sequência das atividades. A história proposta por uma das turmas colocava uma adolescente entre a realização de seu sonho de um intercâmbio fora e usar o dinheiro para pagar as dívidas de seu pai. Outra turma levou sua história para o sofrimento de uma jovem que deixa de almoçar com sua mãe para sair com os amigos, a mãe falece logo após essa recusa e a jovem deve decidir se segue sua carreira e sua individualidade ou abandona para cuidar do pai que ficou sozinho.

De posse das histórias foi trabalhado com as turmas posições éticas de religiões diferentes e assim eles deviam assumir a postura da personagem a partir destas indicações de cada religião. Por exemplo: No Hinduísmo foi trabalhada a noção de carma e suas implicações para as vidas futuras, mas também a relação de castas e a dificuldade de realizar sonhos individuais que rompam com suas origens; no Judaísmo trabalhou-se com os mandamentos que demarcam a importância da família, mas também com a indicação de que no monoteísmo há uma ligação direta entre a ética e a religião, em todos os ambientes em que se esteja; no Islamismo se observou os cinco pilares da fé e a ênfase em uma luta interior para superar os desafios externos; no Ateísmo a valorização do desenvolvimento constante para a formação de uma essência que só pode ser definida pela existência. Assim, em cada abordagem tem se observado como as 
Religare, ISSN: 19826605, v.16, n.1, agosto de 2019, p.228-263.

decisões podem ser diferentes, por vezes levando aos mesmos fins, por vezes conduzindo a novas crises e novas decisões. As teorias vão sendo trabalhadas e internalizadas de uma forma mais lúdica, ao mesmo tempo em que se analisa os próprios contextos dos alunos, que em todo momento são convidados a opinar sobre a suas visualizações das opções tomadas.

\section{Considerações finais}

Com este artigo procuramos descrever os desenvolvimentos legislativos que levaram à proposta de atuação desenvolvida junto à Escola Estadual Adelaide Bias Fortes. As ações iniciadas em 2017 foram revisadas em 2018 tendo em vista a aprovação e publicação da nova BNCC no fim de 2017. Não se está ainda com um trabalho concluído, mas a experiência tem demonstrado que a constante reformulação de objetivos tem sido a melhor ferramenta para que a disciplina seja mais valorizada. Se os primeiros contatos indicavam uma disciplina que tampava buracos de carga horária para os docentes, ou que servia para atender apenas aos projetos estipulados pelas instâncias superiores. Ou ainda uma disciplina catequética para falar do cristianismo ou fazer desenhos evasivos, hoje temos alcançado o respeito da comunidade escolar e, principalmente, dos próprios alunos. Basta tratar a disciplina com respeito, demonstrando conhecimento e preparação, para que os alunos se sintam mais motivados em participar das propostas.

Evidentemente, em uma estrutura em que se lida com 16 turmas de três anos diferentes não serão todos afetados do mesmo jeito, mas, no geral, ao observar que a disciplina não tratava mais de uma proposta catequética ou ecumênica, os alunos passaram a interagir com mais disposição. É interessante como entendem a necessidade de observar uma gama maior de informações para que o ensino seja mais respeitoso. O Estado Laico é respeitado na medida em que a confessionalidade é rechaçada, mas essa postura não é apenas uma questão de 
Religare, ISSN: 19826605, v.16, n.1, agosto de 2019, p.228-263.

rigor teórico, ela representa igualmente uma decisão didática de maior reconhecimento entre os discentes. Certamente os resultados alcançados sofrem uma influência direta da participação dos alunos da UEMG, que com sua atuação permitem que as turmas sejam divididas em grupos menores para debate. Infelizmente vivemos um contexto de turmas cheias o que é diametralmente oposto à uma boa formação.

No atual estágio do processo estamos revisando os resultados do projeto aplicado nos sextos anos, o primeiro a obter um formato mais definitivo, para submeter um novo artigo com indicações de uso da obra de Rick Riordan no Ensino Religioso. Deve-se ressaltar que este autor foi uma indicação dos próprios alunos no primeiro ano de contato com as turmas em 2016. Hoje estamos concluindo um projeto com pesquisas desenvolvidas por alunos de iniciação científica e bolsistas júnior selecionados entre os alunos que fizeram parte do primeiro ano do projeto.

\section{Referências}

BÍBLIA. A Bíblia de Jerusalém. São Paulo: Paulus, 1985.

BRANDÃO, J. Dicionário mítico-etimológico. Petrópolis: Vozes, 2014.

BRASIL. Constituição da República Federativa do Brasil. Disponível em: <http://www.senado.gov.br/atividade/const/con1988/CON1988_05.10.1988/art_ 210_.asp $>$, acesso em 16 de março de 2017a.

BRASIL. Lei $n^{\underline{o}}$ 9.394, de 20 de Dezembro de 1996. Disponível em: <http://www.planalto.gov.br/ccivil_03/Leis/L9394.htm>, acesso em 16 de março de 2017b.

BRASIL. Base Nacional Comum Curricular. 1aㅗ versão. Brasília: MEC, 2015. Disponível em: $<$ http://basenacionalcomum.mec.gov.br/\#/site/conhecaDisciplina?disciplina=AC _CIH\&tipoEnsino=TE_EF $>$, acesso em 15 de março de 2017c.

BRASIL. Base Nacional Comum Curricular. 2aㅗ versão. Brasília: MEC, 2015. Disponível em:

$<$ http://basenacionalcomum.mec.gov.br/documentos/versao-2/areascomponentes $/ 10 \% 20 \% 20$ -

\%20A\%20\%C3\%81REA\%20DE\%20ENSINO\%20RELIGIOSO.pdf $>$, acesso em 15 de março de $2017 \mathrm{~d}$. 
Religare, ISSN: 19826605, v.16, n.1, agosto de 2019, p.228-263.

BRASIL. Decreto $n^{\underline{0}}$ 7.107, de 11 de fevereiro de 2010. Disponível em: < http://www.planalto.gov.br/ccivil_03/_ato2007-2010/2010/decreto/d7107.htm>, acesso em 02 de outubro de 2017e.

BRASIL. Ministério Público Federal. ADI 4.439/DF. Disponível em: $<$ http://www.stf.jus.br/portal/geral/verPdfPaginado.asp?id=635016\&tipo=TP\&d escricao=ADI\%2F4439>, acesso em 02 de outubro de $2017 \mathrm{f}$.

BRASIL. Supremo Tribunal Federal. ADI 4.439/DF - voto do ministro Luís Roberto Barroso (Relator). Disponível em:

$<$ https://d2f17dr7ourrh3.cloudfront.net/wpcontent/uploads/2017/08/VALEESTE ADI-4439-2-Ensino-religioso-Voto-30-ago2017-VF-22.pdf $>$, acesso em 02 de outubro de $2017 \mathrm{~g}$.

BRASIL. Supremo Tribunal Federal. ADI 4.439/DF - voto do ministro Ricardo Lewandowski. Disponível em:

< http://www.stf.jus.br/arquivo/cms/noticiaNoticiaStf/anexo/ADI4439mRL.pdf>, acesso em 02 de outubro de 2017h.

BRASIL. Base Nacional Comum Curricular. Brasília: MEC, 2018. Disponível em: $<$ http://basenacionalcomum.mec.gov.br/images/BNCC_20dez_site.pdf $>$, acesso em 09 de fevereiro de 2018.

CORTELLA, M.S. Educação, Ensino Religioso e formação docente. In: SENA, L. (Org). Ensino Religioso e formação docente: Ciências da Religião e Ensino Religioso em diálogo. São Paulo: Paulinas, 2006, p. 11-20.

EVANS, C.S. Por que os super-herois devem ser bons? Homem-Aranha, os X-Men e o duplo perigo de Kierkegaard. In: MORRIS, M.; MORRIS, T. (Org) Super-heróis e a filosofia: Verdade, justiça e o caminho socrático. São Paulo: Masdras, 2009, p. 157-170.

HOMERO. Odisseia. São Paulo: Cosac Naify, 2014.

HOWE, S. Marvel Comics a história secreta. São Paulo: Leya, 2013.

KNOWLES, C. Nossos deuses são Super-Heróis: A história secreta dos super-heróis das histórias em quadrinhos. São Paulo: Cultrix, 2008.

MENEGHETTI, R.G.K. A pertinência pedagógica da inclusão do Ensino Religioso no Currículo Escolar (conforme a nova Legislação Brasileira). In: GUERREIRO, S. (Org). O estudo das religiões: Desafios contemporâneos. São Paulo: Paulinas, 2003, p. 8999.

MINAS GERAIS. Secretaria de Estado de Educação de Minas Gerais. Ensino Religioso: Currículo Básico Comum do Ensino Fundamental, Belo Horizonte: Governo de Minas, 2014. Disponível em: <https://pt.slideshare.net/toniafeto/cbcanos-finais-ensino-religioso>, acesso em 15 de março de 2017.

MORRISON, G. Superdeuses. São Paulo: Seoman, 2012.

PASSOS, J.D. Ensino Religioso: mediações epistemológicas e finalidades pedagógicas. In: SENA, L. (Org). Ensino Religioso e formação docente: Ciências da Religião e Ensino Religioso em diálogo. São Paulo: Paulinas, 2006, p. 21-45.

PASCAL, B. Pensamentos. São Paulo: Nova Cultural, 1999. 
Religare, ISSN: 19826605, v.16, n.1, agosto de 2019, p.228-263.

RIORDAN, R. O ladrão de raio. 3.ed. Rio de Janeiro: Intrínseca, 2014a. (Percy Jackson e os olimpianos).

RIORDAN, R. O mar de monstros. 3.ed. Rio de Janeiro: Intrínseca, 2014b. (Percy Jackson e os olimpianos).

RIORDAN, R. A maldição do titã. 2.ed. Rio de Janeiro: Intrínseca, 2014c. (Percy Jackson e os olimpianos).

RIORDAN, R. A batalha do labirinto. 2.ed. Rio de Janeiro: Intrínseca, 2014d. (Percy Jackson e os olimpianos).

RIORDAN, R. O último olimpiano. 2.ed. Rio de Janeiro: Intrínseca, 2014e. (Percy Jackson e os olimpianos).

ROBB, B.J. A identidade secreta dos Super-Heróis: A história e as origens dos maiores sucessos das HQs: Do Super-Homem aos Vingadores. Rio de Janeiro: Valentina, 2017.

SÓFOCLES. A trilogia tebana: Édipo Rei, Édipo em Colono e Antígona. Rio de Janeiro: Zahar, 1990.

TEIXEIRA, F. Ciências da Religião e “Ensino do Religioso”. In: SENA, L. (Org). Ensino Religioso e formação docente: Ciências da Religião e Ensino Religioso em diálogo. São Paulo: Paulinas, 2006.

VARDEMAN, R. E; STOVER, M. Godo f War. São Paulo: Leya, 2012.

Recebido em 01/08/2018.

Aprovado em 11/07/2019. 